\title{
Home or Abroad: Vietnamese Refugees' Community Attachment in China
}

\author{
Gan kaipeng \\ Department of social work, Yunnan University of Finance and Economics \\ Kunming, China \\ (937618678@qq.com)
}

\begin{abstract}
The paper studies the community attachment of Vietnamese refugees along the border between China and Vietnam based on previous research findings. The results show that the level of community attachment of Vietnamese refugees is relatively high, the mean score of community identity is the highest, while community alienation the lowest. The variance analysis shows that gender, age and marriage status have not significant impact on community attachment, but born-place and education has significant impact on community attachment. The regression analysis shows that length of residence, education and age have significant influence on community attachment.
\end{abstract}

Keywords-Border, Vietnamese refugees, Community attachment

\section{INTRODUCTION}

In the late $1970 \mathrm{~s}$, due to complex international political situation and anti-Chinese policy carried out by Vietnamese government, a lot of overseas Chinese were forced to flee to China, Malaysia, Hong Kong and Thai from Vietnam, Laos and Cambodia. These refugees were so-called Indochinese refugees which were generally divided into two periods, each with several "waves". The first period began in April 1975 and continued through 1977 . The second period of the Indochinese refugee migration began in 1978 and continues until 1990. A significant characteristic of this period, especially between the years 1978 to 1980, was the large number of ethnic Chinese who migrated out of Vietnam and Cambodia [1]. During the second period, China had received about 280,000 refugees who were settled in 196 state-owned units in Yunnan, Guangxi, Guangdong, Fujian and Jiangxi provinces [2].

However, whether these refugees with unique historical origin and multi-culture have integrated into local society fully after 30 years? How about their community attachment on the refugee communities? From the perspective of safety and stability in frontier areas, the paper analyses the basic situation and influencing factors of Vietnamese refugees' community attachment based on some related theories such as social interaction, ethnic identity and community attachment.

\section{LITERATURE REVIEW}

The word "community" which is derived from the Latin, namely "common things" or "relationship between close friends" was proposed for the first time by Ferdinand Tonnies, a Germany sociologist, in his work Community and Society.
As an important concept in community research field, the term of community attachment had been concerned by academic circles greatly from different aspect such as community attachment, community satisfaction, community identity or community live and so on.

Research on community attachment emerged during the late nineteenth and early twentieth centuries when the effects of rapid industrialization, and urbanization on the quality of social relationships. Wirth (1938) had studied the trends and changes among population size, density, and heterogeneity which brought about by rapid industrialization, and urbanization, and predicted that the social ties and community sentiments would be increasingly weaker in urban areas. Since then, a lot of sociologists have examined community attachment from a linear-development perspective, including urbanization, population size and density, and infrastructure development [3].

On the other hand, some scholars understand community attachment from another approach - the systemic modelsuggests that attachment will be affected by the complexities such as social ties, positions, community organization, population sizes and densities and so on [4]. These researches focus on the challenges for the individual in experiencing the various changes in a complex environment due to rapid industrialization, and urbanization. In a certain sense, people's community attachment would be improved when he or she experiences a complex environment fully. Some study has showed that length of residence, social status, and age on the residents' ability to develop and foster social ties to communities of place have significant impact on community attachment [5]. Goudy (1990) found similar results in his replication of Kasarda and Janowitz's study for rural Iowa communities, wherein length of residence proved to be the most significant indicator of community attachment [6].

In a word, community attachment refers to an individual's commitment to his or her place of residence [7]. These expressions of commitment can either be subjective (affective) or behavioral [8]. Affective community attachment is demonstrated in four different ways: (a) a sense of belonging to the community, (b) a belief that one can have an impact on the community, (c) a feeling that the community can meet personal needs of its members and is satisfying those needs, and (d) expressions of emotional connections with the community and its members [9]. 


\section{METHOD}

\section{A. Sample}

The study used data from the Vietnamese Refugees' Social Identity Survey (2012 to 2013), which was collected by the department of social work of Yunnan University of Finance and Economics, to describe the community attachment of Vietnamese refugees.

The participants in the original study consisted of 227 refugees (60.6\% males and 39.4\% females) from 4 refugee villages across in China-Vietnam Boarder. The mean age of participants was 37.7 years, with a range of 16 to 70 years. Among of these participants, there are 56.7 percent the first generation of refugees who escaped from Vietnam and 43.3 percent the second or third generation of refugees who were born in China.

\section{B. Measures}

A 35-iterm measure was used to measure the community attachment of Vietnamese refugees, which consisted of three dimensions: positive yearning, community alienation and community identity. All items were responded to on a Likert scale ranging from 1 (strongly trust) to 7 (strongly distrust). The measure was reliable $(a=.906)$.

Since community attachment has been shown to correlate with some control variables, we collected data on gender, age, education, born-place and profession. These controls allowed us to examine whether individual characteristics were influencing the community attachment.

\section{Results AND ANALYSIS}

\section{A. Descriptive Statistics}

Table 1 gives means, standard deviations and correlations of all variables. The results show that the level of community attachment of Vietnamese refugees is relatively high $(\mathrm{M}=3.702$, $\mathrm{SD}=0.357$ ), because these refugees have the same cultural origin and escape experience.

Among of three dimensions, the mean score of community identity is the highest $(\mathrm{M}=4.320, \mathrm{SD}=0.615)$, while community alienation the lowest $(\mathrm{M}=2.801, \mathrm{SD}=0.561)$.

Table 1 Descriptive Statistics

\begin{tabular}{llllc}
\hline & Minimum & Maximum & Mean & Std. Deviation \\
\hline community attachment & 2.63 & 4.63 & 3.702 & 357 \\
positive yearning & 2.00 & 5.00 & 4.126 & .745 \\
community alienation & 1.33 & 4.33 & 2.801 & .561 \\
community identity & 1.67 & 5.00 & 4.320 & .615 \\
\hline
\end{tabular}

$* \mathrm{p}<0.05 ; \quad * * \mathrm{p}<0.01 ; \quad * * * \mathrm{p}<0.001$ 。

\section{B. Variance Analysis}

In order to explore the influential factors of Vietnamese refugees' community attachment, we adopt the way of variance analysis. The results show that gender, age and marriage status have not significant impact on community attachment, but born-place and education has significant impact on community attachment $(\mathrm{F}(1,126)=7.92, \mathrm{p}<0.05 ; \mathrm{F}$ $(3,123)=5.229, p=0.002<.01)$. In other words, the second or third generation of refugees has stronger community attachment than their parents with higher mean score and these refugees who have received more education also present stronger community attachment.

Table 2 Multiple Linear Regression Analysis

\begin{tabular}{cccccc}
\hline variance & $B$ & $S_{e}$ & Beta & $t$ & $p$ \\
\hline (Constant) & 3.578 & .338 & ---- & 10.599 & .000 \\
gender & .005 & .068 & .006 & .067 & .947 \\
age & .007 & .003 & .300 & 2.153 & .033 \\
education & .197 & .062 & .302 & 3.192 & .002 \\
marriage status & .008 & .045 & .016 & .178 & .859 \\
born pace & .129 & .104 & .180 & 1.242 & .217 \\
length of residence & .015 & .006 & .366 & 2.641 & .009 \\
\hline \multirow{5}{*}{$R^{2}=.318$, Adjust $R^{2}=.274$} \\
Model & $F=2.685, P=.018$ \\
\hline
\end{tabular}

$* \mathrm{p}<0.05 ; \quad * * \mathrm{p}<0.01 ; \quad * * * \mathrm{p}<0.001$ 。

\section{Multiple Linear Regression Analysis}

The regression analysis shows that length of residence, education and age have significant influence on community attachment $\quad(\beta=0.366, \quad p=0.009<0.01 ; \beta=0.302$, $p=0.002<0.05 ; \beta=0.30, p=0.033<0.05)$, namely, these refugees with longer length of residence, higher education and older age will have stronger community attachment (see table 2).

\section{CONCLUSION}

The paper studies the community attachment of Vietnamese refugees along the border between China and Vietnam based on previous research findings. The results show that the community attachment of Vietnamese refugees is impacted significantly by born place, length of residence and education, while gender, age and marriage status have not significant impact on community attachment. In a word, as a special refugee group, the community attachment of Vietnamese refugees is influenced by some external factors such as original born place, refugee status or refugee villages and so on. In order to promote the social cohesion of Vietnamese refugees, the local government should guide and cultivate refugees' consciousness of citizenship, improve the system of community participation and build up harmonious refugee community.

\section{REFERENCES}

1] Hien Duc Do. The Vietnamese Americans. Greenwood Press, London, 1999, p27.

[2] Liang Shuying. International refugee law. Intellectual property press, 2009, 280-281.

[3] Kasarda, J., \& Janowitz, M. (1974). Community attachment in mass society. American Sociological Review, 39, 328e339.

[4] Hummon, D. (1992). Community attachment: Local sentiment and sense of place. In I. Altman \& S. Low (Eds.), Place attachment (pp. 253-278). New York: Plenum Press.

[5] Theodori, G. L. 2004. Community attachment, satisfaction, and action. J. Commun. Dev. Soc. 35(2):73-86. 
[6] Goudy, W. J. 1990. Community attachment in a rural region. Rural Sociol. 55:178-198.

[7] Liu, Q., Ryan, V., Aurbach, H., \& Besser, T. (1998). The influence of local church participation on rural community attachment. Rural Sociology, 63, 432-450.

[8] Gerson, K., Steuve, A., \& Fischer, C. (1977). Attachment to place. In C. Fischer (Ed.), Networks and places: Social relations in the urban setting. (pp. 139-161). New York: The Free Press.

[9] McMillan, D.W., \& Chavis, D.M. (1986). Sense of community: A definition and theory. American Journal of Community Psychology, 14(1), 6-23. 